\title{
OS UNIVERSOS DO FUTEBOL: \\ UMA ETNOGRAFIA DAS REDES FUTEBOLÍSTICAS EM SÃO PAULO
}

\author{
Enrico Spaggiari ${ }^{1}$
}

\section{Introdução}

Em 2007, iniciei uma pesquisa que teve como objetivo principal analisar o ensino e aprendizado da prática futebolística para crianças e jovens de bairros da Zona Leste de São Paulo, procurando contextualizar as observações de campo com as propostas das políticas públicas de esporte. Foi possível observar que o ensino e aprendizado compreendem diferentes aspectos, mas que aparecem articulados: trabalho, corpo, dom, futebol-arte, peneiras, masculinidade, modelos pedagógicos, profissionalização etc. Para apreender a heterogeneidade de atores e sentidos atrelados ao ensino do futebol, acompanhei as atividades (aulas, jogos, treinos etc.) e observei as redes de relações construídas entre crianças, jovens, jogadores de várzea, pais, olheiros, empresários etc.

A presença freqüente dessa multiplicidade de atores no dia-a-dia durante o trabalho de campo foi se tornando cada vez mais significativa, o que me fez atentar às redes de relações observadas. Assim, marcada inicialmente pela observação em uma escolinha de futebol na Cidade Líder, bairro periférico da Zona Leste paulistana, a pesquisa posteriormente ganhou uma amplitude de atores, experiências, trajetórias e situações que atravessavam os recortes pesquisados. Para compreender este campo multifacetado, tomei um conjunto de experiências, geradas em diferentes cenários e planos de interação, como traçado privilegiado de observação, a fim de acessar configurações mais amplas que se desenham por toda a contextura social.

Um aspecto a problematizar a compreensão da dinâmica relacional característica da escolinha de futebol na Cidade Líder só pôde ser verificado no decorrer do trabalho de campo: a formação de jovens e potenciais jogadores. Se, por um lado, observava o processo de ensino e aprendizado do futebol entre os alunos, pais e professores, por outro, percebia que, concomitante ao ensino, trabalhava-se a idéia da formação dos pequenos jogadores, o que exigia um olhar para outros atores que se relacionam com os

\footnotetext{
${ }^{1}$ Universidade de São Paulo, Brasil.
} 
indicados há pouco. No decorrer das conversas e interações em campo, termos e expressões como "testes", "peneiras", "seleção de garotos" e "indicação" soavam ininterruptamente, tanto nas falas dos adolescentes mais velhos, que trocavam informações de locais e datas para testes, como nas conversas dos atores adultos, que articulavam, cada um a seu modo, contatos com olheiros, ${ }^{3}$ funcionários de clubes de futebol, pais, jovens etc. Há, portanto, um conjunto diversificado de atores sociais envolvido, de alguma maneira, com o processo de formação e seleção de potenciais jovens jogadores. Processo este que se dá, no caso da rede aqui pesquisada, em espaços não espetacularizados. ${ }^{4}$ Etapa diferente da centrada nas categorias de base dos clubes de futebol, já enfrentada por outros autores (Rodrigues, 2003; Damo, 2007).

\footnotetext{
${ }^{2}$ Processo tradicional de seleção de jovens jogadores, as peneiras têm um caráter muito espontâneo: os garotos se cadastram por telefone ou nas sedes do clube e esperam por uma convocação para testes preparados pelos profissionais responsáveis dos clubes. As peneiras, diferente das escolinhas, não têm um caráter de formação de jogadores plenamente institucionalizado. Sua finalidade é selecionar, a partir dos testes realizados com inúmeros jovens, aqueles que se sobressaem nas avaliações e que têm potencial para ingressar nas categorias de base dos clubes. As peneiras, apesar de serem realizadas constantemente, não promovem a seleção da maioria dos garotos que participam dos testes. Ou seja, as peneiras não constituem hoje a principal forma de seleção de jovens jogadores, pois poucos jovens, dos que se apresentam para os testes, são selecionados. E destes, muitos não permanecem nos clubes, pois são dispensados nas etapas seguintes (Toledo, 2002; Damo, 2007), sendo necessária uma etnografia mais detida sobre o universo das peneiras.

${ }^{3}$ Agente muito próximo ao universo futebolístico profissional, que tem como tarefa procurar - incumbido pelos empresários de jogadores e clubes de futebol - jovens praticantes (de diferentes idades) com potencial para um dia serem jogadores profissionais de futebol.

${ }^{4}$ Conferir a problematização de Damo (2002) sobre o uso das categorias amadorismo e profissionalismo, bem como sua interessante classificação que divide as práticas futebolísticas em quatro matrizes: espetacularizada, bricolada, comunitária e escolar (Damo, 2007: 40).
} 
Portanto, após as primeiras observações, realizei uma revisão de alguns dos aportes iniciais da pesquisa, redirecionando as trilhas etnográficas a serem traçadas, com o objetivo de investigar a formação de jogadores, processo que é trabalhado de forma concomitante ao ensino e deste não pode ser dissociado. Temas como peneiras, empresários, política municipal e futebol de várzea aparecem entrelaçados em tal etnografia e mostram-se decisivos no processo de formação dos jogadores. Segui, assim, uma rede social a partir da diversidade de situações, atores e questões observada na Cidade Líder, mas desdobrada principalmente a partir de Guaianases, bairro também localizado na Zona Leste paulistana ${ }^{5}$. Uma rede na qual as conexões não se limitavam aos aspectos espaciais ou interacionais, mas também faziam referência a conexões entre idéias, práticas e representações (Marcus, 1995).

A rede pesquisada, porém, se expandiu a partir do próprio pesquisador, ator também inserido na rede (Latour, 2006). Por meio de um amigo ${ }^{6}$, durante uma partida do Nacional A.C. válida pelo Campeonato Paulista da Série A-2 de 2008, conheci Renato, formado em Ciências do Esporte na Universidade Estadual de Londrina, e que voltara a morar em São Paulo, junto com sua família em Guaianases. A conversa de bar virou troca de informações sobre agenciamento de jogadores. De volta para São Paulo, Renato optou por investir na carreira de empresário de jogador. Para isso, decidiu obter a licença de Agente FIFA para assim ter trânsito oficial entre os diversos clubes. Licença que embora fácil, não é muito barata de se conseguir, comentou Renato. "Mas vale a pena, por que...”. Assim, a rede teve início. Renato organizaria, para as próximas semanas de março de 2008, algumas peneiras em Guaianases. Decidi acompanhar o trabalho desenvolvido por Renato no bairro, que já naquele momento envolvia o Guaianases F. C., clube de futebol varzeano tradicional no bairro. Por meio dos contatos travados pelo agente Renato conheci os principais interlocutores dos próximos recortes etnografados. A rede se ampliava...

\section{Algumas questões sobre conexões e redes}

Este artigo parte de uma estratégia relacionada aos métodos etnográficos

\footnotetext{
${ }^{5}$ Embora a grafia Guaianases seja a correta, segundo dados da Prefeitura de São Paulo, muitos moradores do bairro utilizavam e escreviam "Guaianazes", como era possível visualizar também nos letreiros de diversos estabelecimentos comerciais da região. Um dos interlocutores, inclusive, corrigiu-me durante uma das entrevistas ao perceber que eu anotara no caderno de campo a grafia com a letra S.

${ }^{6}$ A presença de um amigo em comum, que faz a "ponte", é uma estratégia comum no trabalho de campo (Silva, 2000: 35), pois “não se pode menosprezar os significados das redes que 'prendem' o antropólogo aos grupos que observa e aos grupos dos quais ele faz parte" (Silva, 2000: 36).
} 
adotados em pesquisas sobre processos sociais que envolvem múltiplos locais e conexões, aproximando-se, assim, de temáticas já conhecidas no debate antropológico. Para dar conta do meu objeto, proponho uma reflexão sobre as possibilidades em torno de uma articulação entre diferentes abordagens, uma vez que, para aproximar-se da experiência urbana contemporânea, é preciso tecer uma multiplicidade de contextos interligados. Porém, não são locais ou unidades estáveis e homogêneas, já que as situações e os espaços estão conectados em uma dinâmica relacional mais dilatada. Assim, ao privilegiar a descrição da rede de associações, o antropólogo evitaria, assim, a busca por modelos teóricos, categorias e teorias apriorísticas que expliquem as realidades estudadas ou que resolvam possíveis contradições observadas durante a etnografia.

Tem-se, assim, uma imagem relacional da antropologia, ampliada a um plano contínuo de conexões. Nesse sentido, realizar uma etnografia inspirada pelo delineamento de conexões possibilita uma análise antropológica que pode ser feita por meio de distintas propostas metodológicas, tal como as pautadas pela idéia de redes ou as que pensam a conexão etnográfica em diferentes espaços. ${ }^{7}$

No caso desta pesquisa, trata-se de uma rede que se expandiu a partir do próprio pesquisador, atuante tal como os demais atores observados, como bem ressaltou Latour $(2006)^{8}$. Ao mesmo tempo, a construção das redes nos recortes aqui observados pode ser acompanhada empiricamente, tal como propôs Michel Agier (1999), que procurou traçar conexões entre relações locais com identidades mais abrangentes por meio de uma concepção espacializada de redes.

Em seus trabalhos ${ }^{9}$, Agier acompanhou a construção de redes dilatadas que partiam de um núcleo inicial específico e territorializado, marcado pelas relações cotidianas e diferentes formas de sociabilidade (reciprocidades, confiança, clientelismo etc.), e constituído pelas esferas da família, vizinhança, trabalho, lazer etc. Tais relações

\footnotetext{
${ }^{7}$ Problematizar o espaço implica repensar a idéia de lugares e de observação em localidades específicas. Questão presente na multi-sited ethnography de Marcus (1995), que tem como referencial empírico não somente um único espaço ou grupo, mas sim a articulação, num sistema amplo, de uma maior variedade de atores e espaços que estão inseridos no campo relacional do qual os recortes estudados fazem parte.

8 Autor que propôs o método Teoria Ator-Rede (Actor-Network-Theory), uma "sociologia das associações", que consiste em traçar - a partir da prática etnográfica e da descrição - associações, caminhos e conexões entre atores, actantes (não-humanos), incoerências e contextos para, com base na configuração dessas associações traçadas, revelar o fenômeno do social.

${ }^{9}$ Dentre seus inúmeros recortes analíticos, destaco a busca do autor em apreender, a partir de suas etnografias nas partidas e torneios de futebol do bairro Liberdade em Salvador (BA), as situações de interação e construção de redes num espaço mais local, esportivo, masculino e citadino (tal como a pelada intitulada "Baba do Negão") (Agier, 1999: 101).
} 
e sociabilidades, inicialmente vinculadas a um contexto singular, articulam-se e se alargam em redes, ligando os pequenos mundos de cada citadino (os quais Agier denominou "cidade familiar") às macroestruturas sociais. Ampliação e alargamento que podem alcançar redes multilocais (Agier, 1999: 123) e, por conseguinte, o universo urbano em sua totalidade, mas que se dão, porém, de forma elusiva, visto que o tamanho da rede é determinado pelo modo como os desígnios locais e as formas de apropriação citadina de amplas instituições produzem as relações.

Portanto, a partir das situações de interação no nível microssocial, desde as relações mais próximas com parentes, amigos e vizinhos, aos quadros públicos de criação e representação de identidades coletivas, tais redes de relações podem por vezes atingir um nível de expressão nacional (transformando-se em associações e empresas ou sendo incorporadas por instituições). Permanecendo, entretanto, ligadas às mesmas fidelidades e valores relacionais. Assim, é na dinâmica das redes que se desenham os "invisíveis" elos intermediários, esferas por excelência das "sociabilidades alargadas" (Agier, 1999) - entre os pequenos mundos dos citadinos e as macroestruturas sociais nas cidades.

O objetivo deste artigo é, portanto, reconstruir as conexões e trajetos por meio do conjunto de atores que circulam pelas redes de relações que perpassam os universos futebolísticos, sabendo, todavia, que o tráfego se concentrará no plano do futebol nãoespetacularizado e nos pontos de encontro e tensão com a dimensão espetacularizada. Por meio do acompanhamento das redes, que tiveram como ponto inicial a peneira organizada pelo agente de futebol (Renato) pretendo revelar alguns dos meandros do processo de formação de jogadores de futebol em São Paulo. Nesse sentido, uma análise mais sistemática e abrangente ${ }^{10}$ da relação entre os atores permitirá um maior entendimento da pluralidade de práticas e representações do fenômeno futebolístico.

\section{"O agente FIFA filho de Guaianases": seus primeiros passos}

Graduado em Ciência do Esporte pela Universidade Estadual de Londrina (UEL) e Especialista em Fisiologia do Exercício pela Universidade Federal do Paraná (UFPR), Renato nasceu e morou em Guaianases até os dezenove anos. Estudou nas escolas estaduais do bairro, sempre com a "marcação cerrada" da mãe, que limitava os horários

\footnotetext{
${ }^{10}$ Até onde for possível, visto a complexidade de definir, nas pesquisas em recortes urbanos, "quantas e quais as pessoas com quem estabelecer contato, quais os contextos mais adequados para a observação etc.” (Silva, 2000: 39).
} 
para a prática do futebol. Renato jogava na rua da sua casa, nas quadras poliesportivas das escolas e nos campos de várzea do bairro. Porém, sempre dentro do que lhe era permitido e não somente por receio das broncas que receberia de sua mãe:

\begin{abstract}
Sempre teve a questão do risco. Quando era pequeno e jogava na rua, tinha "toque de recolher", entendeu? A partir de um determinado horário, sei lá, eles resolveriam as questões deles e passavam o aviso. Acho que era lá pelas cinco horas. [...] Não sei se era bandido, traficante, o que era, mas eu sei que os caras iam trocar tiros, resolver alguma coisa com alguém, entendeu? Não sei especificar o quê eles eram exatamente, mas era gente dali.
\end{abstract}

Sem poder brincar muito na rua, Renato permanecia boa parte do seu tempo nãoescolar em casa, assistindo televisão, junto com o irmão, dois anos mais velho. Por causa do envolvimento da sua mãe, Renato acredita que ele e seu irmão tiveram uma formação diferente de seus amigos do bairro:

Eu tenho amigos que queriam ter estudado e não conseguiram [...] porque aqui era muito comum você passando para o primeiro colegial, mudar para o noturno e ir trabalhar. Então, a visão de muitos pais daqui é que a pessoa do sexo masculino, com quinze anos tem que levar dinheiro para casa.

Entre todos os amigos de infância, Renato lembrou que apenas Rodrigo "Nenê", um dos seus parceiros nas atuais empreitadas futebolísticas, fez faculdade. Formação gratuita no ensino superior que Renato e seu irmão só descobriram ser possível já mais velhos, por meio de um amigo do irmão: "Eu não sabia que existia faculdade pública". Decidido a entrar em uma universidade, Renato fez o cursinho da Poli, no bairro da Lapa, concomitante ao terceiro ano do colégio estadual em Guaianases e também no ano seguinte, após formado. Sem ter muitas informações sobre os cursos universitários, Renato escolheu Ciências do Esporte por meio de uma revista sobre vestibulares.

Tentou ingressar na Universidade de São Paulo (USP), mas não passou no vestibular. Aceito na Universidade Estadual de Londrina (UEL), não pensou duas vezes em se mudar para lá, embora tenha ficado triste com a grande distância que o separava de sua mãe. "Foi bom. Quando sai daqui, esperava encontrar pessoas diferentes de mim, esperava uma barreira entre eu e eles. Mas não teve muito. Até me identifiquei mais com o pessoal de lá do que com o pessoal daqui”. Em Londrina, para economizar, dividiu apartamento com diversos colegas, a maioria com condições financeiras melhores. Mas isso não atrapalhava muito, "porque a cidade era barata e fazia um controle do que gastava". 
Durante a graduação, fez estágios em escolas públicas de Londrina e ministrou aulas de futebol de campo no projeto Segundo Tempo, do Ministério dos Esportes: "Dei aula numa escola num lugar chamado Cinco Conjuntos, periferia de Londrina, um lugar super populoso. Adorei ter dado aula lá, me senti em casa, me senti à vontade, parecia que eu estava aqui”. Entre as diversas especialidades oferecidas pela área de Esporte (administração, fisiologia, marketing, pedagogia etc.), Renato optou por transitar entre as mais variadas funções, até escolher a profissão de empresário de futebol:

Eu escolhi esse negocio de empresário por acaso. Se você parar para pensar, todos eles [seus colegas de faculdade] tinham uma possibilidade maior do que a minha em relação a investimento. Eu não tinha. Quando fui para Londrina, eu não tinha dinheiro. Lembro que eu passei porque meu irmão estudava em Assis. Minha mãe falou: "Ah, presta lá, é perto do seu irmão.” [...] Quando ela ligou lá na pensão que eu fiquei no vestibular e a mulher falou que era $\mathrm{R} \$ 450,00$ por mês eu falei: "Nossa, não tem como ficar." Mas foi por acaso. Eu acho que tive a sorte, entre aspas, de querer o futebol. Fui para lá sabendo que eu ia mexer com futebol. Não com o quê exatamente. [...] O nosso professor de futebol na primeira semana perguntou: "Quem quer futebol?" A maioria levantou. Só que ele desanimou, falou que era difícil, para ir desistindo. A maioria ali já foi largando e eu persisti.

Para Renato, sua experiência anterior no futebol, de ter jogado em alguns times de várzea e passado por algumas avaliações, foi decisiva para a sua escolha. Sua prioridade, a partir de seu ingresso na faculdade, era aprimorar e diversificar seus conhecimentos, estudando os diferentes planos de atuação dentro o futebol:

No curso, fiz estágio sempre voltado para futebol. Fiz estágio no Londrina Junior Teen, categoria de base do Londrina, que é clube-empresa agora. Dois anos no Londrina Junior Teen, em 2005 fiz estágio no Santos e no final de 2005 no Londrina de novo. Fiz curso de legislação esportiva na época, junto com o Paulo Schmitt, que agora é o relator do STJD [Superior Tribunal de Justiça Desportiva]. Sempre fiz curso de arbitragem. Estudei tudo o que eu achava necessário para o futebol. Estudava por conta muitas vezes. [...] Procurava aprender sozinho mesmo. Fiz a faculdade pensando que me capacitaria teoricamente com o diploma. Quando eu me formei, eu percebi que não era bem assim, só o diploma não era necessário.

Formado no plano teórico, mas distante do conhecimento prático, pouco ensinado na faculdade, Renato entrou no universo futebolístico "no escuro, da mesma foram que eu fiz o curso, sem ter dinheiro, tudo mais". Direcionou seus primeiros passos para a carreira de treinador de futebol. Porém, ficou desanimado logo nos primeiros meses de estágio no projeto Segundo Tempo: “qualquer pessoa dá palpite, porque todo mundo acha que entende de futebol e eu nunca aceitei muito isso, de ter alguém mandando em mim, influenciando no que eu faço". Para não enfrentar estes problemas, decidiu organizar um projeto próprio, "para captar e desenvolver talentos, porque aí eu seria o treinador, eu colocaria minhas idéias". 
Contudo, não conseguia, por meio de seus esforços individuais, acesso aos clubes brasileiros, principalmente os do Paraná e São Paulo, estados que conhecia bem, e os de Santa Catarina, região que visitava sempre por causa na namorada catarinense. Sem espaço no cenário brasileiro, começou a mandar emails para clubes estrangeiros, que demonstravam interesse no seu projeto. Embora a idéia inicial não fosse voltar para Guaianases, "porque eu sabia que aqui não tinha campo", Renato percebeu posteriormente o quanto estava enganado:

Voltando para cá, acabei percebendo que aqui tem uma amostra enorme. [...] Não sei precisar quantas pessoas tem aqui na Zona Leste, mas penso que se aproxima de um terço da população da cidade. Então você tem todo tipo de gente. Você tem branco, negro (e aí já tem diferentes tipos de brancos e negros), tem nordestino, tem gente de tudo quanto é lugar. Tem muita gente de diferentes tipos. Então, o esporte que eu mexesse aqui, eu ia achar talentos, se eu soubesse fazer um trabalho bem feito.

Empolgado com a boa receptividade, retornou para a casa da mãe em Guaianases e decidiu investir tudo o que tinha na tentativa de se tornar um agente FIFA: "Eu pensei: tiro a licença, aqui tem os produtos, os bons jogadores. Só não sei o canal, vou ter que arrumar o canal". Enquanto procurava ampliar sua rede de contatos e os canais de diálogo com os clubes, Renato percorreu diversos campos de várzea da Zona Leste para observar partidas envolvendo equipes formadas por garotos de várias idades, com o objetivo de conhecer o nível técnico médio dos garotos de acordo com a posição, a idade e tipo físico. Além disso, visitou categorias de base de alguns clubes profissionais para compreender qual a rotina de treinamento, os métodos de preparação física, os atributos e qualidades mais valorizados pelos técnicos das equipes de categoria de base dos clubes e, principalmente, como eram feitas as avaliações dos jovens:

\footnotetext{
No futebol é mais "olhômetro". Se fosse atletismo, teria que fazer testes e tudo mais. Mas futebol tem a questão de como a pessoa usa as capacidades que ela tem. Então, eu estou no lugar ideal. Até o rapaz do São Paulo F. C. falou que não sabe como não têm tantos jogadores daqui, que aqui é perfeito para sair. Aí eu pensei nisso e reparei que os clubes não utilizavam isso. Falei: "Vou me antecipar aos clubes." Se eu me antecipar aos clubes como uma pessoa comum, quando eles perceberem, eles vão me atropelar. Sendo "agencista", eles não me atropelariam.
}

Para obter a licença de agente FIFA, Renato estudou para a prova escrita, com quinze questões, em espanhol, elaboradas pela FIFA e cinco, em português, pela CBF. A seleção tem apenas uma prova, realizada por aproximadamente duzentas pessoas: "Se você não passar, tem a oportunidade de fazer depois de graça. Se não passar nessa segunda, você fica dois anos sem fazer o exame, sem poder prestar". Passou com facilidade na primeira tentativa. Porém, o principal entrave neste processo era o 
dinheiro, "a prova é o de menos", afirmou. "A inscrição é $\mathrm{R} \$ 1.000,00$. Depois, se você passar, paga $\mathrm{R} \$ 3.000,00$, um seguro exigido pela FIFA. Depois, a taxa administrativa da CBF, mais $\mathrm{R} \$ 5.000,00$, quando você pega a carteirinha. [...] No mínimo R\$9.000,00 ao todo". Custo total que pode variar:

Aí eu paguei $\mathrm{R} \$ 900,00$ no material. Na verdade, você baixa da internet o material, mas eu queria a prova e o rapaz vendia a prova, então eu paguei $\mathrm{R} \$ 900,00$ pela prova anterior, entendeu? Mas eu não me arrependo, porque foi ela que direcionou os meus estudos. Aí eu observei, fiz a porcentagem lá de quanto caía de determinado estatuto e estudei de acordo com isso. Direcionei meus estudos com isso. Sem contar a viagem para o Rio, uma viagem a mais que eu tive que fazer, porque o correio entrou de greve.

Alto investimento que Renato considera essencial, pois existiriam muitas diferenças nos resultados alcançados de acordo com a posição. "Vale a pena, e o retorno é maior, entendeu? E você entra no mundo do futebol diretamente". E completou:

O status acho que é o principal. Eu sou a mesma pessoa no jeito de ser, me visto igual, ando igual, sou a mesma pessoa, tenho as mesmas idéias que eu tinha antes. Só que, por exemplo, alguém formado em Esporte ter uma idéia é uma coisa. Um agente FIFA ter uma idéia é outro peso, entendeu? Um formado em Esporte levar o menino é um peso, um agente FIFA é outro. [...] Você liga para uma empresa, qualquer empresa, você consegue falar com quem você quiser. Eu fui numa empresa que organiza a Copa do Mundo, empresa internacional, falei com o responsável daqui, entendeu? Mandei um email para a Inglaterra, nem sabia que tinha aqui e a menina me passou para o cara direto e essa abertura eu não tinha, aqui antes, se eu tentasse o projeto que eu queria como formado, eu não conseguiria. [...] Então a relação muda. Se eu for viajar para qualquer cidade amanhã, eu ligo para o clube da cidade, falo que gostaria de conhecer e aí as portas estarão abertas.

Com a carteirinha de agente FIFA na mão, Renato iniciou a construir sua rede de contatos, retomando antigos e criando novos. Neste início, o fato de ser nascido e criado em Guaianases facilitou a realização dos primeiros contatos e a criação de relações mais pessoais com os jovens e seus pais, de diferentes modos:

A relação é próxima. Até com o Renan, o primeiro menino que eu fui na casa. Por eu ser daqui ajuda e por ser negro ajuda, entendeu? Tem essa relação também, o pessoal confia mais. [...] É assim aqui. Se fosse um cara de fora, primeiro, o cara teria medo de vir para cá. Aqui eu ando de qualquer jeito, normal, me meto em qualquer buraco sem problema. Eu sou fisicamente igual o pessoal, entendeu? Se fosse algum de fora ia querer vir, de acordo com a mentalidade da maioria dos agentes, com um carro bonito, ia querer vir arrumado. Já ia correr riscos, entendeu? Eu ando normal aqui e ser daqui ajuda bastante.

Contudo, outro fator acelerou, de forma mais direta, o crescimento da sua rede de contatos. Gabriel, pai de Renato, sempre esteve envolvido com o futebol de várzea. Presidente do Princesa F. C., antigo clube do bairro, Buguinho - modo como Gabriel prefere ser chamado - teve um papel essencial na formação futebolística de seus filhos: 
$\mathrm{Na}$ época em que eu nasci, até 1985 , ele jogava. O clube acabou por algum motivo. Mas aí ele continuou jogando futsal, que era o futebol de salão nos campeonatos dos Correios. Mas ele sempre teve uma relação. Às vezes ele tentava montar time de garotos. Aí ele resolveu voltar com o Princesa.

A popularidade de Buguinho no universo varzeano do bairro facilitou o contato com os clubes locais: "Eu fui conversar com o Itamar [presidente do Botafogo de Guaianases], pois meu pai conhecia ele, entendeu? Eu chego lá, falo de quem eu sou filho. Sempre alguém vai conhecer o meu pai, vai saber que eu não sou qualquer um”. No Guaianases F. C., a aproximação foi semelhante, também mediada por Buguinho.

\section{"Sempre assim, todo mundo quer ser meia ou atacante"}

O primeiro passo de Renato foi o agendamento de peneiras com jovens nascidos em 1990 e 1991. "Meu objetivo era tentar dar um encaminhamento para os meninos mais velhos. [...] Menino de dezoito e dezessete anos, sem passagem em clubes, praticamente morreu para o futebol e já tem que procurar serviço". Para isso, precisava de um campo. Com a mediação de seu pai, conseguiu a liberação do campo do Guaianases F. $C^{11}$. para a realização de suas peneiras: "Meu objetivo não era aqui no Guaianases, podia ser no campo do Princesa, pois meu pai abriu espaço ali”. Porém, optou por utilizar o espaço do Guaianases F. C., já que a diretoria do clube fora bem receptiva. Como contrapartida, ajudaria na reestruturação do clube, que reiniciara suas atividades após um período inativo: "Estou trazendo uma base para os garotos daqui”.

No dia marcado para primeira avaliação da peneira, encontrei Renato na Estação Guaianases, da linha de trem da CPTM. Guiado por ele, fomos até a sede do clube. Diferente da maioria dos campos de várzea que observara, o campo do Guaianases tem pequenas arquibancadas que circundam mais da metade do campo: "Cabe fácil umas 3.000 pessoas aqui”, assegurou Coquinho, presidente do clube ${ }^{12}$. Quando chegamos, alguns garotos já esperavam, ao lado do campo, o início da peneira. Alguns jovens que

\footnotetext{
${ }^{11}$ O Guaianases F. C. foi fundado em 1946, com a junção de duas antigas equipes varzeanas: Atlas Lajeadense F.C, de 1915, e União F.C., de 1934. Por problemas financeiros, o clube encerrou suas atividades por alguns anos, mas retornou ao cenário esportivo da Zona Leste em 2006, com a formação de uma nova equipe de jogadores e a organização de uma escolinha de futebol para crianças e jovens do bairro, com aulas terças e quintas-feiras, na parte da manhã e da tarde.

$12 \mathrm{O}$ campo do Guaianases foi lembrado e destacado por diversos atores, devido às suas grandes dimensões (90 x 66 metros), assim como pela capacidade de abrigar por volta de 3.000 torcedores em suas arquibancadas. Além disso, o campo tem vestiários, banheiros e um bar. Tal estrutura, entretanto, não fora conservada e o campo do Guaianases apresenta hoje várias deficiências, como bem lembrou Buguinho: "Se fosse o meu caso e tivesse um campo como o Guaianases, aquilo ali seria um estádio. Com a visão que eu tenho, seria um estádio, com certeza. [...] Essa visão eles não tiveram. Para você ver a que ponto chegou, o campo está abandonado, virou pasto”.
} 
não tinham feito a inscrição na semana anterior vieram conversar com Renato, para saber se poderiam participar da avaliação. Porém, não puderam se inscrever, pois eram nascidos em 1992 e a peneira naquele dia reuniria somente jovens que nasceram entre 1989 e $1991 .^{13}$

O primeiro dia da peneira foi conturbado. Houve problemas por causa da falta de água potável ao lado do campo, carência de vestiários, campo mal cuidado etc. Vários jovens chegaram atrasados, atrapalhando a formação das equipes. Após meia-hora de espera, um grupo de dez garotos da escolinha Real Madrid de Ferraz de Vasconcelos, comandada pelo professor Oscar, com que pude estabelecer neste dia um primeiro contato. Enquanto os jovens de Ferraz se trocavam no vestiário improvisado ao lado do bar, Renato iniciou a distribuição de coletes para os jogadores. Na primeira tentativa, não conseguiu formar um time completo, pois não tinha zagueiros suficientes. Em voz baixa, Renato comentou: "Sempre assim, todo mundo quer ser meia ou atacante".

Após a segunda tentativa e algumas improvisações, as equipes foram formadas. Antes de iniciar a partida, Renato indicou quais os pontos que seriam avaliados: posicionamento, visão de jogo, rendimento físico, participação defensiva etc.. Pediu, ainda, que evitassem o uso excessivo de força e violência, principalmente nas divididas de bola. A primeira parte da atividade durou quarenta minutos. Após o intervalo, Renato fez algumas trocas de jogadores. Encerrada a segunda metade, que durou trinta minutos, reuniu os jovens no centro do campo. Conversou sobre o desempenho deles, fez algumas orientações individuais e, antes de encerrar, convocou-os para a próxima avaliação que realizaria na semana seguinte. Explicou que a partir destas duas primeiras avaliações, selecionaria aqueles que participariam da terceira e última etapa da peneira.

$\mathrm{Na}$ semana seguinte, acompanhei novamente as atividades. Neste dia, conheci Rodrigo "Nenê", vizinho e amigo de infância de Renato, que também participava das peneiras, ajudando a organizar e selecionar os garotos. "Ele não está tanto na parte de organização, não é a cara dele. Mas ele entende muito de avaliação, por isso está mais na parte de selecionar". Conhecimento futebolístico que Renato já havia destacado em conversa anterior: "Se você quer saber sobre peneiras, o cara para conversar é o Nenê".

"Já vi de tudo, coisas bem bizarras. Teve uma vez que um moleque, atacante bem 'ruinzão', foi aprovado num teste lá em Osasco. A gente soube depois que o técnico tinha jogado com o pai dele no interior e eram amigos. Isso me desmotivava",

\footnotetext{
${ }^{13}$ Renato explicou: "Essa primeira rodada de avaliações é para os mais velhos, aqueles que estão tendo as últimas chances. Daqui uns meses farei uma nova rodada para os nascidos em 1992 e 1993".
} 
comentou Rodrigo, que tentou até os 18 anos tornar-se jogador de futebol. Participou de inúmeras peneiras e foi aprovado em algumas. "O Nenê vivia jogando bola na rua, tinha uma habilidade incrível e era paparicado por vários clubes do bairro", afirmou Renato, que jogou junto com ele no clube Princesa durante um longo período. O pai de Renato confirmou os elogios, porém criticou as atitudes e escolhas de Rodrigo:

O Nenê jogou em vários lugares da várzea. Jogou inclusive no Princesa, por um bom tempo. Fui técnico dele. O moleque tinha talento de sobra e podia ter virado um jogador profissional. Porém, não teve cabeça. Não gostava de treinar, era preguiçoso, acordava tarde, faltava nos jogos. Bem diferente do Renato, que era esforçado, inteligente, mas não tão habilidoso.

Para Buguinho, se "uma máquina de fabricar jogador" juntasse a orientação tática do Renato com a habilidade do Nenê, o resultado seria um ótimo jogador. Mas reforçou que não adianta apenas o talento, se não há dedicação. Embora fosse aprovado nas peneiras, Rodrigo não conseguia permanecer nos clubes por muito tempo: "Nenê tinha muito 'vício de várzea': queria driblar demais, não sabia a hora de chutar para o gol, a hora que passar, às vezes queria marcar o gol no vale tudo". Para o pai de Renato, corrigidos os vícios, um jogador de várzea pode ingressar numa equipe profissional, mesmo se estiver com mais de vinte anos, pois "um jogador com vinte e seis anos tem mais dez anos de futebol [...] Vi muitos jogadores bons, fora de série, na várzea, que jogariam em qualquer time profissional". É o caso de Rodrigo, que ainda poderia ainda tentar a carreira de jogador, com boas chances, avaliou Buguinho. "O Germano, aquele que foi para o Santos, tem 26 anos. O Liédson tinha 26 anos, estava no mercado e alguém acreditou nele".

Embora não esteja no melhor de sua forma, Rodrigo ainda recebe inúmeros e freqüentes convites para participar de equipes de futebol de várzea e de futsal da Zona Leste: "Agora ele estava ganhando de um time de futsal da Vila Carrão. Mas nos outros ele joga porque o pessoal chama e ele não sabe falar não. Às vezes ele nem quer. Muitas vezes acontece dele aceitar dois convites, três, quatro e não ir". Diferente de seu pai, Renato não criticava uma possível falta de compromisso de Rodrigo. Preferia questionar a tradicional estrutura do futebol varzeano e as condições oferecidas aos jogadores:

Meu pai chamava para jogar. Mas e se eu me machucasse? Meu pai é quem cuidava do time, mas se machucasse quem ia se virar era minha mãe. Não era ele. É isso que eu vejo com o Nenê, por exemplo. O pessoal chama e cobra: "Vamos jogar." Mas se ele se machucar, ele quem vai ficar sem trabalhar. O Coquinho, aí do Guaianases F. C., às vezes tenta ajudar, com a influência que ele tem, arrumando remédio e tal. Mas geralmente é assim: você serve enquanto você está jogando, [mas] se você machucou... 
Embora afirme ainda gostar de jogador futebol nas equipes de futsal e de várzea, um possível retorno à rotina de testes e avaliações dos clubes espetacularizados, aventado por Buguinho, foi descartado por Rodrigo, que vêm explorando outras experiências profissionais no campo esportivo. Desfeito o sonho de ser jogador, graduou-se em Educação Física na Universidade Cidade de São Paulo (UNICID) e fez Especialização em Treinamento Desportivo pelas Faculdades Metropolitanas Unidas (FMU). Após se formar, começou a trabalhar como educador no CEU Jambeiro. Junto com outros colegas, era responsável pelas atividades lúdicas das crianças e jovens fora da sala de aula. Comandava, entre outras coisas, as aulas de futebol, basquete, natação e dança.

Em paralelo às atividades como educador, Rodrigo desenvolveu com seu amigo Renato um projeto de formação de jogadores na Zona Leste, que teve início com a organização da peneira no campo do Guaianases F. C., na qual Rodrigo teria uma participação fundamental: definir os critérios de avaliação e indicar os selecionados.

Após as duas últimas duas etapas da peneira, Renato e Rodrigo selecionaram sete jovens e programaram encontros diários com os mesmos já na semana seguinte, para iniciar um rápido ciclo de treinamentos, preparando-os para as avaliações nos clubes. Rodrigo, porém, teve que adiar em dois meses o envio de jovens para testes em certos clubes com os quais já fizera contatos: "Eu tive que segurar porque os campeonatos para a idade deles, o Campeonato Paulista, começa em agosto, então o clube só quer avaliação em julho". Nesse período, decidiu testar o comprometimento e o desempenho dos jovens selecionados, inscrevendo-os em algumas avaliações locais: "O primeiro lugar que eu tentei fazer avaliação foi o Suzano, já para ver a questão da motivação do menino, força de vontade, se ele quer entrar mesmo, se quer só no time que ele acha que é grande. Alguns não levei para não perder, para segurar”. Nos meses seguintes, vários realizaram testes no Paraná, principalmente no Londrina Junior Teen. Outros foram ao Velo Clube, da cidade de Rio Claro, interior paulista.

Apesar de valorizar a qualidade dos sete jovens selecionados, Renato não alimentava muitas expectativas. "Nas peneiras dos clubes a exigência é outra, muito mais difícil e com outros métodos de avaliação", comentou, e em seguida fez uma rápida descrição do processo de seleção nos clubes. Nesses, as peneiras são realizadas por meio de jogos entre duas equipes, formadas aleatoriamente no momento da avaliação. Devido à falta de entrosamento e aos poucos minutos de avaliação, prevalece, na maioria dos casos, o desempenho individual dos garotos, mais preocupados em 
demonstrar seu talento e suas habilidades. Num outro formato, muito utilizado, a peneira opõe os garotos em avaliação contra uma equipe que já faz parte das categorias de base do clube. Nesse caso, o jogo antagoniza uma equipe entrosada e uma equipe formada na hora, sendo que a aprovação de um garoto na peneira pode levar à dispensa de outro jovem que estava na equipe consolidada, conhecida também como "baba" (Damo, 2007: 116-117).

A realização de peneiras deixou ser uma das prioridades dos clubes, segundo Renato. "O número diminuiu, isso é certeza. Acho que eles perceberam que não dava tanto resultado, pois poucos garotos eram selecionados ali. Não compensava o trabalho que dava". ${ }^{14}$ Renato levantou vários motivos para o baixo aproveitamento dos jovens das peneiras. Além da falta de entrosamento, visto que as equipes são formadas no momento do teste por jovens que se desconhecem, há ainda, em alguns casos, a dificuldade de enfrentar uma equipe que já treina nas categorias de base do clube há mais tempo: "Há um pacto entre os garotos dos clubes. Se um novo se destaca, ele tem chances de entrar. [Se] Um de fora entra, um que já está no time pode sair”.

O que é efetivamente avaliado nas peneiras? A dificuldade de definir essa avaliação pode ser explicada, inicialmente, pelo caráter multifacetado do aprendizado futebolístico (Spaggiari, 2009b) que perpassa inúmeros planos e não somente uma dimensão exclusiva:

É difícil especificar. Por exemplo. O Nenê aprendeu de tanto jogar, só ficar na rua jogando, de morar em frente à quadra. Eu não aprendi assim. Aprendi mais observando, mais com a cabeça. Usava o meu físico para jogar, mas sem uma técnica apurada. [...] Na medida do possível tinha algum destaque, apesar de não ter a prática que os meninos bons da época tinham. Eu conseguia, por exemplo, marcar eles, mesmo não jogando todo dia. Eu conseguia ficar pensando no jogo, ou ver um jogo de futebol, ou jogar no videogame e perceber como eu poderia anular cada um. ${ }^{15}$

Embora citasse sua própria trajetória para argumentar sobre a não existência de uma fórmula específica, Renato acreditava que a prática exaustiva e o ambiente de aprendizado eram as duas principais explicações:

Por que o Ronaldinho joga mais que o Kaká? Não sei, são da mesma posição, mas o Ronaldinho é um jogador super habilidoso. A habilidade vem da prática, vem do treino. Se a pessoa tiver um cognitivo, ficar tentando fazer um negócio lá o dia todo, ela vai aprender uma hora como fazer da melhor forma possível. O Kaká não faz

\footnotetext{
${ }^{14}$ Permanece, porém, como uma forma de recrutamento de jovens, embora apresente números baixos de aprovação e aproveitamento posterior no clube, como verificaram alguns estudos anteriores em São Paulo e Porto Alegre (Toledo, 2002; Damo, 2007).

${ }^{15}$ A prática de futebol no videogame foi analisada anteriormente (Spaggiari, 2009).
} 
isso, mas é bom jogador também. [...] Talvez o Adriano tenha aprendido num clube, na rua ou de outra forma. Mas aí também tem muito da abordagem. O Adriano pode ter treinado muito o chute, só fazer gol. Agora o Nenê, porque alguém ou algum ídolo dele fazia jogada bonita, ele ficava treinando jogadas bonitas. Vai muito do foco de cada um. O ídolo do Kaká era o Raí. Ele já teve o foco mais direto. Parece que ele aprendeu a jogar em clube, parece até um jogador europeu: toca a bola bem, se mexe bem, tem um físico privilegiado, tem os fundamentos bem trabalhados. Eu o classificaria como um jogador de escolinha.

A posição a ocupar em campo também fundamenta a definição dos atributos que um jogador de futebol deve apresentar. Para Renato, a qualidade técnica do jovem não pode ser dissociada da posição em que ele joga, pois seu talento pode ser facilmente desperdiçado se estiver jogando na posição errada. Na segunda peneira organizada por Renato, o jovem Fernando (90), ${ }^{16}$ muito alto e magro, iniciaria o treino como centroavante, tal como jogara na primeira peneira. Rodrigo "Nenê", porém, pediu para que ele jogasse, naquele dia, como zagueiro-central. Contrariado, o jovem atendeu ao pedido. Nas duas partidas daquela tarde, foi considerado um dos melhores jogadores em campo, "roubando" várias bolas ao antecipar-se aos atacantes adversários, mas principalmente mostrando talento com as bolas nos pés, nas saídas de jogo, armando o time e arriscando algumas subidas ao ataque. Neste dia, teve um desempenho melhor do que na peneira anterior, quando jogou de centroavante. Por causa destes últimos treinos, foi um dos aprovados na avaliação. Perguntei a Rodrigo como ele percebeu que Fernando poderia jogar de zagueiro: "Ele tem altura, porém não é estabanado, tem velocidade. Mostrou que tinha habilidade como centroavante, mas não tanto quanto outros que vi jogar. Além disso, chutava pouco para gol". ${ }^{17}$

Para além das peneiras realizadas em clubes, ocorrem avaliações em diferentes lugares e momentos, organizadas por empresários e agentes de futebol, como também pelo poder público. Durante a Virada Esportiva ${ }^{18}$, por exemplo, alguns clubes, em parceria com a prefeitura do município, agenciaram peneiras para garotos de 12 a 17 anos. Diversos sites da internet também se propõem a organizar peneiras em diversos clubes brasileiros. Leandro (90), que participou da peneira organizada por Renato,

\footnotetext{
${ }^{16}$ Farei um uso sistemático destas indicações entre parênteses, que fazem referencia ao ano de nascimento do entrevistado. Por exemplo: Renan (92) indica que ele nasceu em 1992, Marcos (01) assinala que ele nasceu em 2001. A idade é uma informação essencial nos universos dos recortes pesquisados, pois definem: momento da iniciação esportiva, etapas do aprendizado, momento das tentativas de consolidação da carreira de jogador, idade escolar, procura de empregos etc.

${ }^{17}$ Características assinaladas por Damo (2007: 132): estatura, imposição funcional, desarme, capacidade de recuperação e antecipação seriam as principais características específicas esperadas de um zagueiro para virar jogador profissional; estatura, imposição funcional e finalização seriam as dos atacantes.

${ }^{18}$ Inspirada na Virada Cultural, a Virada Esportiva oferece atividades em inúmeros espaços citadinos (praças, ruas, parques e outras áreas públicas) durante todo o dia, inclusive de madrugada.
} 
comentou que por meio da internet teve contato com a Júnior Nunes Football Management, uma empresa de representação e gerenciamento de jovens jogadores, que realizou peneiras no SESI-Osasco, das quais Leandro participou, em busca de garotos para serem negociados com clubes de outros países.

"Para mudarem de vida, os moleques tentam de tudo hoje em dia, vão atrás de qualquer chance. Vêem na TV os jogadores com carros importados, mulheres, roupas caras e pensam: por que não eu?", afirmou Renato. As diversas histórias de jogadores que alteraram sua condição social por meio do futebol alimentam a dedicação dos jovens, sendo que alguns justificavam estar ali para um dia, por meio do futebol, poder ajudar a família. "É fato. A maioria dos jogadores vem das classes baixas, que têm pouca renda. Por isso é que o futebol é visto como um meio para mudar de vida", comentou Pãozinho, professor da escolinha do Guaianases F. C.

Jean (89), lateral-direito, afirmou orgulhoso que seu pai estava ali presente no campo do Guaianases no dia peneira, dando apoio, incentivando; diferente, segundo o jovem, dos pais de alguns dos seus amigos que reprovavam o sonho dos filhos. Seu pai, ao contrário, fazia de tudo para que ele tivesse os melhores equipamentos (vestimentas, chuteiras, remédios), ao mesmo tempo em que exigia e cobrava empenho e dedicação nos treinos. "Uma vez ele quase brigou com um cara lá num teste no Flamengo de Guarulhos, pois o cara falou que eu era bom, mas muito molenga e preguiçoso... disse que eu só gostava de atacar e não de marcar”.

A presença dos familiares pode, segundo Renato, atrapalhar no início da carreira, porém considerava que na maioria dos casos ajuda, devido à influência deles sobre os filhos, tal como na conversa que observei na peneira no Guaianases F. C., quando o pai tentava o convencer o filho a aceitar a proposta do Renato de viajar para jogar no A. E. Velo Clube, da cidade paulista de Rio Claro: "eu sei que você quer jogar em um clube grande, destes de torcida de massa, porém tem que começar onde aparecer a primeira chance, como o empresário disse, mesmo que seja num clube pequeno".

Portanto, a possibilidade de ascensão social e ganhos financeiros ajuda a conquistar o apoio da família, decisivo para os primeiros passos na carreira e um futuro sucesso nos campos de futebol. Sucesso almejado por Fábio, pai de um garoto que participou da peneira organizada por Renato: "Eu torço muito para que ele consiga. É a chance de dar uma nova vida para a nossa família. Ele tem cinco irmãos mais novos, que dependem dele". O filho de Fábio foi um dos selecionados por Renato. Neste, como em outros casos, o investimento na carreira de jogador é, em muitos casos, um projeto 
familiar (Rial, 2008: 33-39), principalmente na trajetória dos jovens das classes populares. ${ }^{19}$

Embora tenha gostado dos resultados da primeira peneira que organizou, Renato decidiu postergar uma segunda peneira que estava programada para junho de 2008 e investir em outras linhas de trabalho que vinha planejando desde que concluiu a graduação na faculdade. Conhecedor da dinâmica imprevisível do universo espetacularizado, Renato procurou diversificar sua atuação, deixando as peneiras em segundo plano: "Precisava ter alguns garotos 'na manga' para iniciar as primeiras negociações. Mas preciso agora é de contatos fortes", afirmou.

\section{O modelo exógeno do Grupo Pão de Açúcar}

Poucos meses após retornar de Londrina, Renato procurou um colega da faculdade, seu veterano no curso, que trabalhava como assistente do José Carlos Brunoro, ${ }^{20}$ diretor de futebol do Grupo Pão de Açúcar. A partir deste contato, ficou decidido que Renato observaria algumas partidas dos jovens do Pão de Açúcar e de seus adversários, faria avaliações das performances e indicaria os melhores. Esse era o principal interesse do Grupo, que iniciou suas atividades apostando num modelo de formação de jogadores, porém não para uso do próprio clube, mas para a venda de jogadores formados ainda jovens. Foco principal de um projeto que, segundo Brunoro, ${ }^{21}$ também tem uma preocupação social (Spaggiari; Mizumoto, 2006). ${ }^{22}$

O padrão inicial de formação de jogadores adotado pelo Pão de Açúcar se encaixa, dentre os três modelos de produção de jogadores formulados por Damo

\footnotetext{
${ }^{19}$ No caso específico de Fábio, o projeto familiar está centrado atualmente no primogênito, que se dedica somente aos processos de seleção e avaliação. Diferente, portanto, do padrão caçulismo observado por outros autores (Damo, 2007; Rial, 2008) e em certos momentos desta pesquisa.

${ }^{20}$ Conhecido por sua atuação no voleibol - como jogador, preparador físico e técnico -, Brunoro ingressou no universo futebolístico na década de 1990, como diretor de esportes da filial sul-americana da empresa italiana Parmalat. Em 1992, coordenou o primeiro sistema de co-gestão no patrocínio esportivo no Brasil, quando articulou e consolidou o consórcio da multinacional com a S. E. Palmeiras.

${ }^{21}$ Este depoimento faz parte do documentário Por que o Juventus? (Spaggiari; Mizumoto, 2006) sobre o C. A. Juventus, tradicional equipe paulistana, que abordou também a parceria firmada em 2005 entre o clube e o Grupo Pão de Açúcar. A parceria envolvia, inicialmente, apenas a categoria de juniores do Juventus, com um trabalho que visava dar continuidade aos trabalhos anteriores do Grupo com as categorias de base. Em 2006, a parceria se estendeu à profissional. Porém, após menos de um ano, o Grupo Pão de Açúcar voltou a concentrar seus investimentos na formação de jovens jogadores.

${ }^{22}$ Segundo Brunoro, o "projeto do Pão de Açúcar não envolve ter uma super equipe. O projeto tem um cunho social. Tem uma parte dos meninos de uma grande seleção que vai para uma escola de varejo do Grupo. A outra parte que vem para cá para ser um atleta de futebol, a gente também está encaminhando ele para uma profissão de atleta de futebol. Mas deixando bem claro, como eu sempre fiz. Não adianta se iludir que aqui vamos um criar um novo Palmeiras, um novo Corinthians ou um São Paulo. Não é essa a nossa missão, nem a missão do Grupo Pão de Açúcar” (Spaggiari; Mizumoto, 2006).
} 
(2007), ${ }^{23}$ no formato exógeno, direcionado para a venda dos jogadores formados. Tratase, porém, segundo Renato, de uma estrutura diferente de muitos clubes do interior que atualmente são gerenciados por agentes de futebol, que passam a ser responsáveis pela contratação de jogadores e pagamento de salários. Nestes casos, os agentes montam equipes formadas com jogadores a eles vinculados, para que estes jogadores disputem os campeonatos e apareçam para a grande mídia: "Quem se destaca, é vendido. Até mesmo aqueles mais fracos conseguem ser negociados hoje em dia. Assim, todo mundo vai embora e o clube tem que montar um novo time a cada ano", afirmou Renato.

O agente de Guaianases acompanhou várias partidas da equipe Pão de Açúcar e dos adversários, fez anotações e escreveu alguns relatórios que foram encaminhados à diretoria de futebol. Ao longo de todo o período, não teve retorno financeiro. Assim, optou por diminuir sua freqüência nos jogos das equipes do Grupo, para se dedicar a um projeto que vinha ganhando força no seu próprio bairro.

\section{"Uma parceria bem com a cara do Corinthians"}

Enquanto realizava as peneiras, Renato e alguns dos diretores do clube Guaianases F. C. formularam um projeto para a criação de um Centro de Formação de Jogadores, cuja matriz seria o próprio Guaianases, mas que depois se ampliaria para outros lugares. Além de Rodrigo "Nenê", que ajudou na elaboração do projeto, Renato pretendia convidar seu pai para participar do planejamento e das atividades diárias. Convite que Buguinho aceitaria prontamente:

Se pintasse mesmo, com certeza ia trabalhar com ele. Principalmente com moleque para a gente investir. [...] Teria que se preocupar mais com médico, com massagista. [...] E trabalhar nos dois períodos, porque os horários escolares variam. Seria um trabalho muito interessante. Eu tenho certeza que num espaço [de tempo] bem curto, a gente conseguiria bons valores lá.

Experiência que Buguinho teve ao selecionar, nos campos de futebol espalhados pela Zona Leste da cidade, jovens jogadores para os quadros juvenis do Princesa, quando era dirigente do clube na década de 1980: "Naquela época não tinha escolinha.

\footnotetext{
23 Os clubes de futebol, segundo Damo (2007: 124-144), podem ser divididos em três modos de produção: endógeno, exógeno e híbrido. No primeiro, os jogadores são formados para atender às demandas por atletas internas ao próprio clube, como, por exemplo, ocorre no Atlético de Bilbao, da Espanha. No segundo, a formação tem o intuito único de obter lucro por meio da venda de jogadores, como era o caso do Pão de Açúcar. O terceiro modelo é o mais comum, identificável na maioria dos clubes brasileiros e estrangeiros, onde a produção de jogadores ocorre tanto para a venda quanto para suprir a necessidade de jogadores para compor os elencos do próprio clube.
} 
O que acontecia? Eu ia aos campos de futebol, via o moleque jogando bem, falava: 'Você leva jeito, hein, meu? Você não quer jogar no Princesa?'”.

O projeto foi enviado ao S. C. Corinthians Paulista, que possui um Centro de Treinamento (CT) no bairro vizinho de Itaquera, por meio de Coquinho, presidente do Guaianases e sócio do Corinthians, e Pedrão, que fora segurança da equipe principal do Corinthians por muitos anos e é um dos diretores mais antigos do Guaianases. Contatos esses que, segundo Renato, foram decisivos para garantir uma primeira rodada de negociações com a diretoria corintiana:

Renato: A idéia acabou surgindo sem querer. É bem coisa de futebol, coisa de Corinthians. Foi quando surgiu minha relação com o Coquinho [presidente do Guaianases F. C.]. Eu precisava de alguém para levar o projeto para lá e ele ajudou na campanha do Andrés Sánchez [atual presidente do Corinthians].

E: O Coquinho ajudou na campanha do Andrés Sanchez?

R: Isso.

E: Como ele ajudou?

R: O Coquinho sempre foi da Gaviões. ${ }^{24}$ Ele sempre teve uma liderança aqui, com a torcida e tudo mais. [...] Não sei se você tem perguntado do Corinthians, mas tem muita gente da Gaviões lá. O Coquinho era sócio também. E aí ele aproveitava para andar lá. Não só na parte do futebol: ia na bocha, fez amizade com todo mundo e o Andrés precisava de voto. Os votos dos menores, mas que faziam diferença. E o Coquinho conseguiu esses votos. Aí ficou prometido esse projeto. Assim que surgiu.

A proposta era de promover, em conjunto com o Corinthians, o ensino da prática futebolística para um público com idade entre 7 a 17 anos, com um total inicial de 210 alunos, divididos em três categorias: 1992-1993, 1994-1995 e 1996-1997. Com atividades da escolinha programadas para terça-feira e quinta-feira, o projeto separava a sexta-feira para treinamento das equipes de competição e o sábado para amistosos e campeonatos destas equipes. A parceria envolveria ainda o direcionamento de jovens do Guaianases F. C. para testes e avaliações nas categorias de base do Corinthians.

Destes 210 alunos, um pequeno percentual teria isenção de mensalidade, principalmente as crianças carentes que moram em Guaianases, o que reforçava a preocupação social como principal tema apresentado no projeto de parceria, cujos principais objetivos, apontados pelos diretores do Guaianases, eram: educar e socializar as crianças e adolescentes, promover a integração e inserção social, reduzir a evasão escolar, afastar os jovens da violência e das drogas, ensinar valores éticos e morais da

\footnotetext{
${ }^{24}$ O Grêmio Gaviões da Fiel Torcida é a maior torcida organizada do S. C. Corinthians Paulista. Fundada em 1969, a torcida é também um escola de samba do carnaval paulistano.
} 
cidadania, criar oportunidades de lazer, diminuir a permanência das crianças e jovens nas ruas e, por fim, difundir e incentivar a prática de futebol. ${ }^{25}$

A preocupação social foi, portanto, um ponto destacado por diretores do Guaianases F. C., que compararam seu projeto ao da parceria firmada entre o Botafogo de Guaianases, clube rival, e o São Paulo F. C. no final de 2007. Para eles, diferente da parceria entre o São Paulo e o Botafogo, que visava somente investir em crianças de até 13 anos, a proposta de trabalho em conjunto com o Corinthians pretendia abarcar garotos de todas as idades, até no máximo dezoito anos: "Senão, não é projeto social", justificou Renato, para quem o interesse do Corinthians devia-se também ao receio de perder espaço para um clube rival numa das regiões mais populosas da cidade e que é, costumeiramente, associada à equipe alvinegra:

\begin{abstract}
Inicialmente, seria uma resposta ao projeto Botafogo de Guaianases-São Paulo. O coordenador falou: "Não, [a Zona Leste] é nossa área". Só que foi crescendo a idéia, crescendo e crescendo. O pessoal do Corinthians sabia que eu era agente também. [...] A idéia agora é levar o Corinthians a diversos lugares, não é nem só nas regiões periféricas leste, oeste, norte e sul. Fazer um projeto social mesmo, envolver verbas do governo e tudo mais. O negócio vai ser grande. No mês que vem vai sair.
\end{abstract}

Contudo, o projeto elaborado no primeiro semestre de 2008 não seguiu adiante. Programada para julho de 2008, a assinatura do contrato não foi firmada. O projeto foi cancelado pelo Corinthians, que considerou alto ${ }^{26}$ o valor a ser investido: "Talvez pelos gastos, que nem são altos assim, mas em se tratando de dinheiro, tudo fica mais difícil”, postulou Renato. "Uma parceria bem com a cara do Corinthians: está parada".

\title{
"Daqui três anos eu vou ser uma marca"
}

Quando iniciou seu trabalho com o Guaianases F. C., Renato teve a preocupação de não estabelecer vínculos de exclusividade com este ou com outros clubes do bairro. Enquanto esperava os desdobramentos das negociações da parceria com o Corinthians, Renato retomou alguns antigos contatos no Grêmio Botafogo de Guaianases, ${ }^{27}$

\footnotetext{
${ }^{25}$ Com base nos elementos que compunham o texto de abertura do projeto.

${ }^{26}$ Entre os gastos previstos, parte do dinheiro seria para a compra de equipamentos, tais como: 30 cones, 320 coletes, 40 bolas, 40 colchonetes, 2 jogos de uniforme, 50 pares de caneleira infantil, 6 pares de luvas de goleiro, 6 agasalhos, 8 redes, 4 cronômetros, 1 bolsa de massagem, 2 pranchetas, 2 fitas métricas, uma balança etc. Outra parte da verba iria para o pagamento dos três professores e do coordenador do projeto. Por fim, o orçamento previa que mais de $60 \%$ dos gastos seriam com despesas de viagens para campeonatos regionais, nacionais e internacionais - que abarcariam a viagem, estadia e alimentação de 18 jogadores e dois membros da comissão técnica -, assim como na organização e treinamento de equipes infantis e juvenis para a disputa dos torneios.

${ }^{27}$ Fundado em abril de 1955 pelo carioca Admardo Armond, morador de Guaianases, o Grêmio Botafogo disputa suas partidas no campo instalado ao lado da Avenida Nova Radial, prolongamento da antiga
} 
intermediados por Rodrigo "Nenê". Assim, procurava não ser reconhecido como um agente ligado a um clube, principalmente quando envolvia dois tradicionais clubes do bairro, Guaianases F. C. e Botafogo de Guaianases, que alimentam uma forte e tradicional rivalidade:

\begin{abstract}
Eu busco não ter vínculo com os clubes daqui. O pessoal tem muito isso: ou Botafogo ou Guaianases. Mas isso para mim, não. Agora tem o Botafogo e o Guaianases, mas daqui três anos eu vou ser uma marca, provavelmente mais forte que eles. Então não penso em ter vínculo. Se quiser ceder o espaço, vai ser bom para o clube, mas não vou fechar com um para ser exclusivo. Se vou lá no Guaianases para ser exclusivo, é para não mais falar com o Botafogo.
\end{abstract}

No clube botafoguense, o objetivo de Renato era articular uma ampla avaliação para a seleção de jovens talentos por meio de um torneio de categorias de base. A estrutura atual do time, principalmente de sua Escolinha Comunitária, permitiria a reunião de diversas agremiações e escolinhas no campeonato, por conseguinte, garantiria a participação de centenas de jovens na disputa. Além disso, Renato vislumbrava uma possível inserção no trabalho realizado na escolinha de futebol do Botafogo, pois segundo o agente, as escolinhas também podem funcionar como mediações entre os jovens e os clubes: "Uma pequena parte vem das escolinhas franqueadas. Pouquíssimos hoje saem de peneiras. A maioria dos clubes hoje pega jogadores de equipes amadoras da capital e do interior para as categorias de base, indicados por olheiros espalhados pelo Brasil", comentou Renato, que citou o trabalho realizado por São Paulo F. C. e Cruzeiro E. C., clubes que têm uma grande rede de olheiros e funcionários em todas as regiões brasileiras.

Contudo, os planos iniciais de Renato tiveram que ser alterados após as primeiras conversas com os diretores botafoguenses Severo Ramos e Luiz Moura, seus principais contatos no clube. Nas negociações, as duas partes acertaram que montariam times com jovens jogadores da escolinha do clube, que viajariam para enfrentar as equipes das categorias de base de diversos times brasileiros: "Na primeira vez que eu vim no Botafogo, minha idéia inicial não era nem formar um time. Era organizar um campeonato de base. A partir daí, achei mais fácil a idéia do time", afirmou Renato. Neste trabalho em conjunto, o contato com os clubes ficaria sob responsabilidade dele, a quem Severo chamava de "o agente FIFA filho de Guaianases", e os custos e despesas

Avenida Radial Leste. Hoje um dos mais famosos clubes de várzea da cidade de São Paulo, o Botafogo dispõe de uma estrutura pouco comum no universo varzeano. 
de viagem seriam bancados por Luiz Moura. Deste modo, sua função seria a de encaminhar garotos da escolinha para clubes interessados.

Entretanto, não estava claro para o agente quem era afinal o seu parceiro no projeto: se era Luiz Moura, dirigente do Botafogo e presidente da empresa que patrocina o clube, ou a própria agremiação. Embora o objetivo de formar jogadores de futebol estivesse claro, assim como a proposta de gerenciamento das carreiras dos jovens, Renato não sabia, naquele momento, qual retorno o Botafogo obteria, pois não conseguia compreender a organização administrativa do clube:

O Adonias [diretor do Botafogo] me perguntou: 'Como que é lá no clube, tal, quanto que eles dão?' 'Dão $20 \%$ para quem leva o jogador'. Mas o problema é: $20 \%$ para quem? Para o Itamar [presidente do Botafogo]? Para o Botafogo? Para o CNPJ, se o clube tiver? Para o Adonias?

Posteriormente, Renato descobriria que esta nova linha de trabalho vinha sendo construída à margem das atividades do Botafogo e que o retorno financeiro pelo encaminhamento de jovens jogadores era para Luiz Moura: “Com o Botafogo eu não tenho nada, é com o Luiz. Se o Luiz sair daqui, eu saio também. Eu não tenho vínculo com o Botafogo", concluiu Renato. A partir daquele momento, ficou claro para o agente não só com quem estava trabalhando e negociando, como também que havia encontrado uma complexa configuração futebolística, marcada por disputas internas, busca por visibilidade midiática, conflitos com pais e mães dos alunos da escolinha, relações políticas locais e municipais etc.

\section{"Vou ter um empresário, agente, procurador, assessor..."}

Embora tenha diversificado seu trabalho em Guaianases, criando várias frentes de atuação, Renato ainda não tivera retorno financeiro em suas empreitadas futebolísticas desde que retornara para o bairro em 2007. Para poder se sustentar e continuar investindo em seus projetos, o agente participava dos negócios e contratos imobiliários que seu sogro e sua namorada gerenciavam em Florianópolis. ${ }^{28}$

O primeiro retorno financeiro vinculado ao universo futebolístico viria de uma forma inesperada. Desde que se tornara agente FIFA, Renato enviava, semanalmente, emails para clubes e empresas européias, principalmente da Inglaterra. Ocasionalmente,

\footnotetext{
${ }^{28}$ A namorada e o pai dela firmaram alguns contratos com uma empresa do exterior que queria investir no setor de imóveis em São Paulo. Quando precisavam, Renato reunia os documentos necessários e entregava a papelada nos escritórios e cartórios de São Paulo por eles indicados. Assim, recebia algumas comissões quando os contratos eram formalizados.
} 
recebia alguns retornos por email ou em suas páginas no MySpace e Facebook. ${ }^{29}$ Num período de férias em Florianópolis, ainda em 2007, leu uma notícia sobre um grupo de empresários nigerianos que atuavam no futebol inglês e em diversos setores de entretenimento na Inglaterra. Entrou em contato e mandou currículo: “Como eles eram de origem africana, fiz contato também pelo Facebook, que tem fotos. Achei que com a minha foto poderia facilitar, por ser negro". Após um longo período, já em 2008, Renato recebeu um email da empresa gerenciada por estes empresários nigerianos, que solicitavam algumas informações de jogadores brasileiros talentosos que poderiam se destacar num futuro próximo. "Enviei coisas sobre o Keirrison do Coritiba, Hernanes do São Paulo, Douglas Costa do Grêmio e outros".

Na segunda troca de emails, o grupo de investidores pediu para Renato informar seus telefones de contatos. Pouco tempo depois, um dos diretores ligou para a casa dele. Nesta primeira conversa, o empresário comentou sobre uma oferta que eles receberam para negociar um contrato publicitário com os agentes do Robinho. Após novas conversas por telefone, o mesmo diretor acertou com Renato os termos de sua participação neste negócio: "Era uma proposta publicitária de uma empresa de telefonia da Malásia. Precisavam do Robinho por três horas, que receberia 100 mil libras". Renato ficaria responsável pela mediação entre a empresa dos investidores nigerianos e os agentes do atacante, pondo-os em contato. "Minha função era deixar tudo 'mastigadinho', já quase acertado". Por este trabalho, Renato receberia 5\% do valor total pago pela agência de publicidade ao jogador.

Renato atribui tal acesso ao fato de ser credenciado pela FIFA, posição que concede status: "Ser credenciado é outra história. Não é um agente de porta de vestiário, como vários por aí". Pediram, posteriormente, para fazer novas intermediações com os empresários de outros jogadores, que ele espera repetir quantas vezes for necessário, pois não exige um grande esforço e o retorno é muito alto: “O trabalho maior é achar os agentes. Pesquisei e em 30 minutos já tinha os contatos. Agora é esperar”, afirmou.

Seu trabalho como agente, entretanto, não implica em posições fixas: "Procurador pode ser outra pessoa, ou ser a mesma que o agente também", comentou Renato, para quem essa confusão no uso dos termos tem como causa a proliferação e multiplicidade de atores que trafegam pelo universo futebolístico e que fazem parte da carreira do jogador. "Tem ainda o assessor do jogador, que cuida dos contatos com a

\footnotetext{
${ }^{29}$ Sites de rede social para a comunicação online entre internautas.
} 
imprensa e a mídia, agenda entrevistas, participação em programas de TV, essas coisas".

São denominações que muitas vezes confundem as crianças e jovens que tentam se tornar jogadores. Observando uma das peneiras realizada por Renato no campo do Guaianases, iniciei uma conversa com alguns meninos que jogavam bola ao lado do bar, a poucos metros do campo. Uma criança falou: "Vou ter um empresário, agente, procurador, assessor...". Outra criança, ao lado, complementou brincando: "Ventilador, carburador... até outro jogador vou ter (risos)". Quando perguntei qual era a diferença entre um empresário e um agente de futebol, os meninos não souberam responder. Questionado por um deles, eu também não soube diferenciar. "A grande dificuldade é que os agentes são popularmente chamados de empresários. Mas tem muito empresário que entra para ter lucro e ganhar dinheiro, porém não tem registro na CBF ou na FIFA, como os agentes têm" afirmou Renato. Embora concorde que as funções de agente e empresário tenham muitas semelhanças, ele apontou as especificidades na atuação de cada um desses atores: procurador, empresário e agente de futebol. ${ }^{30}$

Após realizar o serviço de mediação na negociação do contrato publicitário, Renato procurou, por meio do contato com o grupo nigeriano, impulsionar sua carreira de agente FIFA. Elaborou relatórios sobre alguns jovens de Guaianases, inclusive alguns dos que foram selecionados na peneira que havia organizado, para despertar o interesse dos investidores e de clubes europeus. Sabia, contudo, que a construção destes vínculos não seria fácil, pois desde 2007 tentava, sem êxito, se aproximar de clubes internacionais. Segundo ele, com a extinção gradual do passe após a aprovação da Lei Pelé, proliferou o número de empresários de futebol e de outros atores autônomos: "É muita concorrência, não pode ficar esperando. Tem que correr atrás. Mesmo que seja

\footnotetext{
${ }^{30} \mathrm{O}$ procurador, segundo Renato, é quem tem autorização, por procuração, documento no qual o jogador concede a um terceiro o direito de atuar em seu nome e de seus interesses, assinada pelo jogador e pelos pais (quando menor de idade), a cuidar dos negócios em seu nome, "para correr atrás de clubes, legalizar documentação na CBF ou na FIFA, negociar com empresas de propaganda etc.", afirmou. O agente de futebol tem as mesmas atribuições do procurador, porém se dedica somente ao cenário futebolístico, por isso "procura trabalhar com vários jogadores ao mesmo tempo e ter mais chances de faturar", explicou Renato. Tanto no caso do procurador quanto no do agente, a remuneração poder ser uma porcentagem do salário que o jogador recebe, normalmente entre $5 \%$ e $10 \%$, ou um pagamento fixo por serviço prestado como no caso da intermediação que Renato fez para do contrato de publicidade do jogador Robinho. Empresário, dentre estes, é o ator mais conhecido no universo futebolístico, espetacularizado ou não: "É o termo mais utilizado até hoje para todos os casos. E hoje em dia todo mundo é empresário ou tem empresário, aquele cara que cuida de todas as questões envolvendo os atletas", comentou. Apesar de a denominação englobar diversas funções desempenhadas por outros atores no universo futebolístico, o empresário pode, segundo Renato, ser definido pela intermediação nas negociações entre clubes. Mesmo sem ter contratos assinados com jogadores, o empresário participa de momentos pontuais dessas negociações.
} 
fora do futebol". Mas Renato afirmou ter consciência de que está "engatinhando na carreira", preparando-se para saltos mais ambiciosos nos próximos anos.

"Estou fortalecendo minha base, para depois colher os frutos. Ainda estou na fase de inserir os garotos nos clubes, depois tem a etapa de manter eles lá", comentou, confirmando algo que afirmara para os jovens no primeiro de peneira no campo do Guaianases: o ingresso nos clubes não significa assegurar a continuidade da carreira. No segundo dia de peneira, Rodrigo "Nenê" revelou que alguns amigos do bairro chegaram a entrar nas categorias de base dos clubes, porém foram dispensados nas etapas seguintes, antes de chegarem à categoria dos juniores. Josias, morador do bairro e que acompanhava a nossa conversa naquele momento, reforçou:

Entrar em um clube não é o mais difícil. O mais foda é se manter lá. Meu filho mais velho jogou no juvenil do Corinthians e da Portuguesa. Mas não conseguiu passar para os juniores dos dois times e foi dispensado. Tentou mais algumas vezes, mas acabou desistindo. Hoje trabalha lá na Penha, como atendente de uma farmácia.

\section{Considerações finais}

Durante a realização do terceiro e último dia da peneira organizada por Renato, conversei por mais de uma hora com Rodrigo Nenê. Entre tantas perguntas, num certo momento ele comentou que jogara em diversos clubes do bairro: no Princesa, no Guaianases F. C. e no Botafogo de Guaianases. Quando perguntei sobre este último, Rodrigo se surpreendeu: "Como assim? Você não conhece o Botafogo? Pô, é o maior clube da região e tem uma escolinha. Vamos fazer o seguinte: semana que vem vou te levar lá. A gente se encontra no CEU e depois te levo no campo do Botafogo".

Assim, a rede ampliou-se para o Botafogo de Guaianases, que mantém uma Escolinha Comunitária de Futebol e um contrato de parceria com o São Paulo F. C., assinado em setembro de 2007, para a formação de jovens jogadores na Zona Leste. ${ }^{31}$ No Botafogo, pude observar os primeiros passos da parceria com o São Paulo, assim como os treinos e atividades práticas ministradas pelos técnicos e professores da Escolinha de Futebol Comunitário do Botafogo de Guaianases. Detive-me, principalmente, nas questões de bastidores da escolinha do Botafogo, imersas num

\footnotetext{
${ }^{31}$ A proposta consiste no auxílio, por parte do clube do Morumbi, na formação de jogadores, com o empréstimo de materiais e instrumentos de treinamento, além da participação de profissionais do São Paulo nos treinos diários. Por meio do acordo, o São Paulo terá exclusividade num posterior intercâmbio dos jovens até 13 anos. Os meninos selecionados por profissionais do São Paulo nos campos do Botafogo realizarão testes e, se aprovados, começarão a treinar com o restante dos jogadores no Centro de Treinamento de Cotia, município da Grande São Paulo, que concentra todas as equipes das categorias de base do São Paulo e os jogadores em formação do São Paulo.
} 
conjunto de práticas políticas locais, relacionadas não só ao bairro, mas também à política no âmbito municipal.

Posteriormente, outros recortes foram pesquisados para compreender as redes observadas na Zona Leste, entre eles: Pequeninos do Jockey - sediado próximo de Taboão da Serra (SP), na zona sul de São Paulo -, mencionado constantemente como entidade de referência no ensino de futebol para crianças e jovens, bem como no trabalho de formação e direcionamento dos garotos; escolinha Real Madrid, de Ferraz de Vasconcelos (município paulista localizado próximo à Zona Leste), que conheci num dos dias de realização das peneiras organizadas pelo agente Renato em Guaianases e que pude acompanhar, inclusive, numa viagem até São Lourenço (MG), onde foi realizado um torneio regional de futebol para categorias de base durante o feriado de Corpus Christi em 2008. Ampliava-se, assim, a rede.

Portanto, os desdobramentos do trabalho de campo, iniciado em 2007, foram as razões principais para as mudanças durante a pesquisa, isto porque certas questões só foram abordadas tendo em vista o que era observado em campo. Deste modo, as propostas partiram, fundamentalmente, da experiência dos atores e das situações concretas observadas no campo, para assim reconstituir práticas, conflitos e trajetórias. A pesquisa teve, portanto, um enfoque nas relações etnografadas, que conectam uma pluralidade de pessoas, configurando redes de relações com os mais diversos atores sociais inseridos nesse universo interacional.

Este foi um dos objetivos desta pesquisa: traçar, a partir das descrições e análises ao longo dos capítulos, as conexões entre os diferentes recortes, dos primeiros aos últimos contatos. Jovens, pais, empresários de futebol, Botafogo de Guaianases, Grupo Pão de Açúcar, São Paulo F.C. e Pequeninos do Jockey atravessam uma rede de relações articulada por práticas cotidianas - políticas, midiáticas, educacionais, comunitárias - acionadas não só no bairro, como também para além dele, alcançando outros planos citadinos. Uma pluralidade de temas, objetos e questionamentos que permitem problematizar e compreender algumas das inúmeras mudanças estruturais que o futebol brasileiro vem sofrendo, tanto no seu plano espetacularizado quanto nas formas ativadas cotidianamente nos espaços urbanos.

\section{Referências}

AGIER, Michel. L'invention de la ville: Banlieue, township, invasions et favelas. Paris: Ed. des Archives Contemporaines, 1999. 
DAMO, Arlei S. O uso dos termos amadorismo e profissionalismo como categorias sociológicas na literatura acadêmica sobre o esporte. In: ENCONTRO ANUAL DA ASSOCIAÇÃO NACIONAL DE PÓS-GRADUAÇÃO E PESQUISA EM CIÊNCIAS SOCIAIS, 26., 2002, Caxambu. Programa e resumos... Caxambu: Anpocs, 2002. v. 1, p. 76.

DAMO, Arlei S. Do dom à profissão: a formação de futebolistas no Brasil e na França. São Paulo: Hucitec/Anpocs, 2007. 359 p.

LATOUR, Bruno. "Como terminar uma tese de sociologia: pequeno diálogo entre um aluno e seu professor (um tanto socrático)". In: Revista Cadernos de Campo, no 14/15. São Paulo: USP, 2006. p.339-352.

MARCUS, George E. "Ethnography in/of the World System: The Emergence of MultiSited Ethnography." In: Annual Review of Anthropology, v. 24, 1995. p.95-117.

RIAL, Carmen. S.. "Rodar: a circulação dos jogadores de futebol brasileiros no exterior". In: Horizontes Antropológicos, v. 14, n.30, 2008. p. 21-65.

RODRIGUES, F. X. F. A formação do jogador de futebol no Sport Club Internacional (1997-2002). Porto Alegre: UFRGS, 2003. 199 f. Dissertação (Mestrado em sociologia), Universidade Federal do Rio Grande do Sul, 2003.

SILVA, Vagner G. da. O antropólogo e sua magia: trabalho de campo e texto etnográfico nas pesquisas antropológicas sobre as religiões afro-brasileiras. São Paulo: Edusp, 2000.

SPAGGIARI, Enrico. Tem que ter categoria: construção do saber futebolístico. São Paulo: USP, 2009. 276 f. Dissertação (Mestrado em Antropologia Social). Universidade de São Paulo, 2009a.

SPAGGIARI, Enrico. "Meu professor é a bola": a dinâmica multifacetada do aprendizado futebolístico. In: Ponto Urbe. São Paulo, n.5, $2009 \mathrm{~b}$.

SPAGGIARI, E.; MIZUMOTO, L. Por que o Juventus? Direção Enrico Spaggiari; Leandro Mizumoto. Produção: Enrico Spaggiari; Leandro Mizumoto. Roteiro: Leandro Mizumoto. Edição: Pedro Biava; Thiago Yoshinaga. São Paulo: PUC/SP, 2006. 1 DVD (26 min.), son., color.

TOLEDO, Luiz H. de. Lógicas no Futebol. São Paulo: Hucitec/Fapesp, 2002. 